\title{
Teaching the National Written Language to Deaf Students: A New Approach
}

\author{
Laura Volpato $^{1(\mathbb{\otimes})}$ (D), Marlene Hilzensauer ${ }^{2}$ (D), Klaudia Krammer ${ }^{2}$, and Melanie Chan ${ }^{2}$ \\ ${ }^{1}$ Università Ca' Foscari, Dorsoduro 3246, 30123 Venice, Italy \\ laura.volpato@unive.at \\ 2 Alpen-Adria-Universitaet, Universitaetsstrasse 65-67, 9020 Klagenfurt, Austria \\ \{marlene.hilzensauer, klaudia.krammer, melanie.chan\} @aau.at
}

\begin{abstract}
Deaf people across Europe struggle to have equal access to written information as the main language of instruction in school is the spoken language. The "Deaf Learning" project (2015-1-PL01-KA204-016) aims at improving the above-mentioned situation by developing a face-to-face course supported by a Moodle course according to the needs of young deaf adults. Within the project, the partners developed a framework for lessons ranging from A1 to B2 (on the basis of the Common European Framework for Languages, CEFR) to improve reading and writing skills in the respective national languages. The teaching materials for level A 1 consist of 30 lessons in pdf printable version, and 6 Moodle lessons. To make the course suitable for the very heterogeneous group of deaf learners, the structure of the lessons was designed so that teachers can adapt it to the needs of the deaf students. The Moodle lessons are kept simple and visual; they include sign language videos, images, and H5P interactive contents. The teaching materials have been tested in Italy for the main target group (17 participants aged 16-25 years) and in Austria for all other interested parties (3 participants aged over 30 years) through face-to-face lessons. The participants' feedback was incorporated into the materials.
\end{abstract}

Keywords: Sign language $\cdot$ Deaf education $\cdot$ E-learning $\cdot$ Inclusive learning Bilingual approach

\section{Educational Problems: The State-of-the-Art}

As they cannot hear, deaf people are visually oriented and prefer to use the visual channel for communication. Each country has its own sign language $(s)^{1}$ and dialectal variants. The national sign language is the first language or the preferred one for many deaf people. However, they live surrounded by a hearing majority that mainly communicates through the national spoken/written language(s). In most European countries, spoken language is the language of instruction in schools - a language that does not meet the communication needs of deaf people. Lip-reading is very hard to do over extended periods of time and only $30-40 \%$ [7] of the information are visible on the mouth, i.e. deaf people

\footnotetext{
${ }^{1}$ A country can have more than one national sign language, as it can have more than one national written/spoken language.
} 
have to guess most of the contents. Although international research shows the efficiency of the bilingual teaching method (sign language and written language) for deaf students, it is still rare in Europe [9-11]. When leaving compulsory school, deaf students often have large gaps in their national written language knowledge. This leads to the fact that deaf people do not have equal access to written information. That, among other things, reduces their chances on the labor market and leads to a low self-esteem.

In Italy as well as in Austria and in other European countries, even teachers and tutors for special needs are not specifically trained to teach deaf students (e.g., most have a very low sign language competence) $[1,10]$. As a result, the educational plans, which should be tailored to the deaf individuals, are often limited and lack adequate methodological settings.

Depending on the type of school, the sign language support differs. In mainstream schools there is normally no sign language support; in inclusive classes, deaf students are provided with interpreting services only for a few hours a week and not for every subject; besides, they have to concentrate on the signing of the interpreter and they find it very difficult to take notes or participate actively in the lesson. There are too few interpreters and they would need a special training for most of the school subjects, especially in secondary and higher education. Even in most schools for the deaf, sign language support is limited, as mostly spoken language is the language of instruction.

These problems with teaching the national written language result in poor reading and writing competencies $[2,3,5,10,13]$.

\section{A Proposed Solution}

To improve the above-mentioned situation, the "Deaf Learning" project (2015-1-PL01KA204-0165; homepage: www.pzg.lodz.pl/deaflearning) ${ }^{2}$ developed a face-to-face course supported by a Moodle course according to the needs of the deaf target group, namely young deaf adults aged between 16 and 25 years. All of the partners ${ }^{3}$ have experience within the educational field of the deaf.

\subsection{Structure of the Course}

Within the project, the partners developed a framework for lessons ranging from A1 to B2 (on the basis of the Common European Framework for Languages, CEFR). The teaching materials for the A1 level were fully prepared (in a pdf printable version), including a Moodle course for the six A1 lessons of the first theme.

The course is divided into five themes/topics: Relationships, Sport and Free-Time, Money, Travel, School and Career. Each topic consists of six lessons, which have been

\footnotetext{
2 "The European Commission support for the production of this publication does not constitute an endorsement of the contents which reflects the views only of the authors, and the Commission cannot be held responsible for any use which may be made of the information contained therein".

${ }^{3}$ The project consortium consists of five partners: Poland as coordinator; Austria, Italy, Lithuania and the United Kingdom.
} 
planned by taking into account both the target group, with all its specific features, and the language teaching strategies currently in use for regular second language learners.

A lesson cycle was developed: it starts with the presentation of the new topic and ends with the assessment of that same topic and the introduction of the following one. One of the specific features of the course is that this proposed lesson cycle can be easily adapted to the needs of the deaf students, as they are a heterogeneous group of learners [6], whose initial language competence is very difficult to assess. Within this cycle, either the course modules can be placed in different order, or the teacher can spend more time on one module and skip another one. Sign language plays a crucial role in the education of most deaf students, even if they are at different competence levels: it is the only element capable of bringing deaf learners together, raising their interest and motivation. Therefore, the lessons follow sign-bilingual methods such as Purposeful Concurrent Use, Preview-View-Review and Translation [4].

\subsection{The Supporting Moodle Courses}

Nowadays Moodle has spread in all areas of e-learning, from language education to vocational trainings. This is one of the main reasons behind the choice of Moodle as the tool for the e-learning course. For the students who have already worked with Moodle it will be easy to use the "Deaf Learning" courses. The others will be able to transfer the experience they will gain here also to other contexts. In addition to this, Moodle has the advantage that it is relatively easy to handle, and it offers the possibility to include videos and interactive exercises in a much easier way than e.g. WordPress, which had been used in a previous project.

The Moodle courses are based on the materials developed for the face-to-face course. For deaf students, it is vital to keep the structure as uncluttered, simple and visual as possible. Sign language videos and images are provided wherever they are needed (with a focus on grammar topics and explanations). Moodle offers various possibilities of how to structure the course. For the Austrian version (Moodle version 3.4), a thematic structure was chosen.

The texts developed for the course had to be adapted and simplified to allow independent learning without the help of a teacher. Where possible, the visual attractiveness of the contents was improved by using H5P interactive contents like "Accordion" (e.g. for the different types of questions) and "Course presentation" (e.g. for different forms of greetings).

Students can try out what they have learned in the face-to-face course with interactive exercises (for the Austrian course, also done with H5P), e.g. identifying nouns or verbs in a text with "Mark the words". Most of these exercises are self-correcting and they give the students a visual feedback as well, e.g. they show which nouns/verbs were missed by highlighting them.

H5P also allows the use of videos within exercises. For example, the students can practice their vocabulary by first watching videos of signs in their native sign language and then writing down the respective word in the written language of their country. 


\section{Practical Impact}

At the beginning, the course aims at introducing any new topic in sign language and at activating the written vocabulary related to the lesson. Slowly, the familiar code makes way for the unfamiliar one: the written national language. The second step is achieved through comparisons between the respective signed and written languages (contrastive method), pointing out the similarities and the differences between both systems. In order to test this approach, trial lessons were held in Italy and in Austria. While Italy focused on the main target group, i.e. young deaf people aged 16-25, Austria delivered the lessons to older deaf people (aged over 30). Since the final products of the project will be open access resources, we expect older deaf people to also benefit from them. Similarities and differences were observed during the trials in AT and IT.

\subsection{Trial Lessons in Italy}

In Italy, 11 lessons of 80-100 min were delivered to a group of 17 students. The lessons were divided into two main sessions according to the division in themes. Session 1 consisted of 6 lessons A1 level, theme 1 (Relationships). Session 2 consisted of 5 lessons A1 level, theme 2 (Sport and Free-time). 10 students aged 16-25 were involved in session 1; the lessons took place during school hours, hosted by the secondary Specialized School for the Deaf I.S.I.S.S. Magarotto in Padua. 5 out of the 10 students were not Italian but moved to Italy during their childhood or later. 9 students were involved in session 2; the lessons took place in the afternoon, after school hours, at the residential house of the above-mentioned school. 2 out of the 9 students were not Italian. All students were deaf or hard of hearing and they were all sign language users. The teacher was a hearing native speaker of Italian with very good sign language competence.

All partners agreed to use online assessment tools already available for (hearing) second language learners and proposed a list of such websites. The assessment of the Italian deaf students' competence in the national written language was attempted repeatedly because of two main reasons: the students' resistance against the idea of being assessed; and the failure of the feedback delivery system of the first website employed. One side effect of this situation was that results from two websites could be compared, showing whether the results were different or equal. Two different online language tests were administered ${ }^{4}$. From the first website only 3 out of 6 participants received the results $(\mathrm{P} 1=\mathrm{B} 1 ; \mathrm{P} 2=\mathrm{A} 2 ; \mathrm{P} 3=\mathrm{A} 2)$. From the second website, all 6 received their results: most of the respondents' competence in Italian showed to be higher than A2. In particular, the three participants who completed both tests and received proper feedback scored as follows: $\mathrm{P} 1=\mathrm{B} 1 ; \mathrm{P} 2=\mathrm{A} 2 / \mathrm{B} 1 ; \mathrm{P} 3=\mathrm{A} 2 / \mathrm{B} 1$. Even if three participants are not enough to draw significant conclusions, the comparison between the first and the second assessment shows that the latter gave slightly higher results than the first one. It is

\footnotetext{
${ }^{4}$ Assessment session 1: http://www.torredibabele.com/it/Corsi_di_lingua_italiana/Test_on_ line.html; assessment session 2: https://www.esl.ch/it/soggiorno-linguistico/tests-online/testd-italiano/index.htm.
} 
unlikely that the higher scores are the result of an actual improvement, given that one session is probably too short a time to trigger an increase in the language competence.

The lessons were delivered in written form through Keynote presentation and supported through Italian Sign Language (LIS) according to the sign-bilingual strategies of Purposeful Concurrent Use and Preview-View-Review [4]. Other materials which were employed are: an interactive smart board, portable white boards, a regular blackboard, pens, paper, and computers. After each lesson, the teacher noted down the duration of the lesson, the rate of attendance, which activities had been successful or unsuccessful, and some personal comments.

At the end of the second session, due to the gradual decrease in the rate of attendance, the students were asked for an interview, in order to find out the reasons of the attendance phenomenon. Only 6 students agreed to be interviewed. The questions investigated their likes and dislikes for the lessons, their preferences among the proposed activities, and their suggestions to improve the course. The interviews were carried out in LIS with the support of written text, and they were video-recorded.

All the important remarks collected through the trials and the interviews can be related to three main issues: lack of motivation, need for flexibility, and heterogeneity. Starting from heterogeneity, the group of learners has proved to vary extremely concerning the competence in both sign and written language. Some grammar elements typically included in the A1 level were not grasped by the learners assessed as B1, and vice-versa, higher-level topics were well mastered by students assessed as A2. Despite knowing from the existing literature $[12,14]$ which peculiarities are found amongst written Italian productions by deaf people, the grammar difficulties arose unexpectedly from different students at different times during the lessons. With the students being such a heterogeneous group, it was necessary to adapt the lesson to individual needs; for instance, the teacher had to spend some time individually with each student to revise previous topics. This required the teacher to show a great deal of flexibility. Finally, motivation proved to be the biggest obstacle to the learning process. As previously mentioned, most deaf learners struggle with the national language during their school years and they refuse to face it again, especially if they are in their last years of secondary school, when they already imagine a learning-free future. In order to foster their inner motivation, the partners agreed to interview deaf role-models who achieved high job positions and possess a good competence in the national written language. During the lessons, some strategies to raise motivation were used, such as: give the students more responsibility (e.g. assign specific roles in tasks); use their competitiveness in a positive way (e.g. language games in teams); and praise the students' efforts.

\subsection{Trial Lessons in Austria}

The trial lessons in Austria lasted from September 2017 to February 2018; all lessons of the first three themes of A1 were taught. The setting of the trial lessons, as well as the participants (number and age) were quite different from the ones in Italy. In Austria, the trial lessons took place at the Alpen-Adria-Universitaet Klagenfurt with three deaf participants. These participants were all co-workers at the university and competent sign language users. As mentioned before, most deaf people have problems with learning 
their written national language, regardless of their age. Although the main target group of "Deaf Learning" are young adults (16-25 years), those who are older and want to improve their national written language competence should not be excluded. Therefore, deaf co-workers who were older than 30 years offered to test whether the course content and the methods are appropriate for this extended target group. All three participants showed great interest in improving their written language competence.

As it was done in Italy, an online assessment task of written German competence was administered ${ }^{5}$ before starting with the trial lessons. According to CEFR, all three participants showed a B1 language competence. The teacher was a hearing native speaker of German with very good sign language competence.

At B1 level, students are expected to be familiar with - at least - the basic grammar concepts and terminology (e.g. word classes, declination, and inflection) of a language. It can also be assumed that at this language level, students are able to read and understand the content of a text. As it turned out during the trial lessons, this was not the case ${ }^{6}$. Especially during the grammar module of the lessons, their self-confidence and threshold of frustration were rather low. They often struggled with the grammar terminology and the (grammar) content. After being taught German for at least 9 years in compulsory education (with spoken German as language of instruction), their grammar knowledge was shockingly low, which must be seen as the logical consequence of the respective teaching method. For example, they could mostly add the correct article to a common noun, but they were unable to use the correct declined forms of the articles. It must be noted that the problems of the deaf participants (declination, flection, word-order as well as a limited vocabulary) coincide with the problems described in the literature $[2,8,13]$.

The limited vocabulary constitutes a major obstacle to gaining information from a text. As it turned out during the trial lessons, the participants had problems with reading a text and answering questions about it. At this language level (A1), the texts are very short and easy to understand, nevertheless the deaf participants were often unable to extract the relevant information from the text. Creating short texts on their own proved also a very difficult task for them. They clearly preferred exercises where they were asked to combine phrases or to put given words/sentences into the correct order. It was easier for them, when, before writing an actual text, they had the opportunity to experiment with role-playing. According to their feedback, understanding and writing a text was much easier for them this way.

What pushed their motivation was a positive competitiveness when they exchanged their work. While correcting each other's work, they also asked more questions than during the normal class.

The feedback of the deaf participants from the trial lessons was included in the development of the final version of the teaching materials. Overall, they liked the visual layout. In some cases, small alterations to exercises and/or texts were done by the course designers, based on the deaf participants' suggestions.

\footnotetext{
${ }^{5}$ The test did not include any listening or talking exercises (https://www.alpha.at/de/deutschlernen/einstufungstest-deutsch/).

${ }^{6}$ This shows that the language competence test that was used did neither capture the full range of their knowledge nor the respective lack of it.
} 


\subsection{Common Grounds and Differences Between Italy and Austria}

It was interesting to compare the experience from the trial lessons in Italy with the one from Austria, as the age of the participants as well as the setting of the lessons were quite different.

First, the common grounds: both groups (in AT and IT) had a far poorer competence with regard to their written language than their hearing peers and exhibited a rather low level of tolerance towards frustration. Due to their education experience, they give up much easier than most of their hearing peers would. Both in IT and in AT the knowledge concerning the national written language differed between the participants. This is consistent with the international literature, which describes deaf students as a heterogeneous learning group [6]. Some grammar themes from A1 were unknown to the participants, whereas they were quite familiar with themes from higher levels like B1. The teachers in both countries had to react flexibly to meet the needs of the different students - far more than when teaching hearing students.

Looking at the differences, it turned out that the motivation of the participants to attend the lessons was higher in AT than in IT. The explanation is quite simple: the Austrian participants had the advantage of being familiar with the teacher, they were able to attend the lessons during their normal working hours and at their working place, while the Italian students were busy with other school matters as well. The participants in Austria also had experienced the importance of a good written language competence in their lives - being aware of the consequences of the lack of it.

The trial lessons in IT and AT showed that there are some key facts for successful lessons with this learning group: it is very important to create a positive, welcoming and comfortable learning environment, more than with hearing students. They need the feeling of being "safe" and that making mistakes is an important part of the learning process instead of a failure on their side (as they remember from their previous school experience). The teachers should be able to flexibly adjust their teaching to the different knowledge levels of the students. This might imply to deviate from the prepared lesson plan as well as from the lesson cycle. It turned out that offering deaf students an active role and individual responsibility during the lessons as well as helping them discover what knowledge they already possess served well to awaken the interest of the participants and to motivate them further.

\section{Conclusion and Planned Activities}

The challenge in this project was to create written national language courses, which took into consideration two peculiarities: first, they had to meet the learning needs of deaf students and second, they had to be suitable for "false" foreign language learners. In fact, deaf people have a certain command of their written national language - as it is the language of the majority and they learned it at school - whereas foreigners normally do not have this knowledge when beginning to learn another language. However, the language competence of the deaf students is mostly poor, which leads to the conclusion that the teaching methods in the schools are not at all suitable for those deaf students who use sign language as their first language. Based on this fact, the "Deaf Learning" 
project designed a structured course for teaching the national written languages of the five partner countries (i.e. English, German, Italian, Lithuanian, and Polish). The course takes into account the needs of deaf students and their preference for visually based learning. This course provides the target group, and all those who are interested in improving their competence in the respective national written languages, with an opportunity to work on their reading and writing skills, tailor-made to their needs and preferences. It is a crucial first step towards an equal access to education.

The further course of action will consist of different dissemination activities to promote the course in the project partners' countries. As mentioned above, many teachers of the deaf are not trained enough for this special learning group. It is therefore crucial to spread the information about this course and especially the course method amongst schools for the deaf, inclusive schools, and teachers of the deaf as well as the deaf themselves via national/regional deaf associations.

During the trial lessons, it turned out that the students would need a preparatory course to understand linguistic concepts like noun and verb as well as the different building blocks of written and signed languages. Therefore, the Polish coordinator of "Deaf Learning" will submit a follow-up project consisting of 18 e-learning lessons with signed videos and short assessment activities. The lessons will focus on both general language knowledge (e.g., what is language, what are language families, bilingualism, etc.) and on the aforementioned general concepts (e.g. how do languages express movement/activities).

\section{References}

1. Bertone, C., Volpato, F.: Le conseguenze della sordità nell'accessibilità alla lingua e ai suoi codici. EL. LE, vol. 1, no. 3, pp. 549-580 (2012)

2. Eisenwort, B., Vollmann, R., Willinger, U., Holzinger, D.: Zur Schriftsprachkompetenz erwachsener Gehörloser. Folia Phoniatrica et Logopaedica 54(5), 258-268 (2002). https:// doi.org/10.1159/000065198

3. Eisenwort, B., Willnauer, R., Mally, B., Holzinger, D.: Selbsteinschätzung und Wünsche gehörloser Erwachsener in Österreich bezüglich ihrer Schriftsprachkompetenz. Folia Phoniatrica et Logopaedica 55(5), 260-266 (2003). https://doi.org/10.1159/000072156

4. Gárate, M.: ASL/English bilingual education (Research Brief No. 8). In: Visual Language and Visual Learning Science of Learning Center. Washington, DC (2012). http:// v12.gallaudet.edu/files/3813/9216/6289/research-brief-8-asl-english-bilingualeducation.pdf. Accessed 18 Apr 2018

5. Holzinger, D., Fellinger, J., Strauß, U., Hunger, B.: Chancen Hörgeschädigter auf Eine Erfolgreiche Schulische Entwicklung (CHEERS). Eine Studie gefördert von der Gesundheitsabteilung des Landes Oberösterreich und dem Fond Gesundes Österreich (2006). https://www.barmherzige-brueder.at/unit/issn/sprachundtherapiezentrum/wissenschaft. Accessed 21 Mar 2018

6. Knoors, H.: Language use in the classroom: accommodating the needs of diverse deaf and hard-of-hearing learners. In: Diversity in Deaf Education, pp. 222-223 (2016)

7. Krammer, K.: Einblicke in das Leben einer 'Laut'-losen Minderheit. Gehörlose Frauen in Kärnten. Veröffentlichungen des Zentrums für Gebärdensprache und Hörbehindertenkommunikation, Band 14. Klagenfurt (2008). https://www.aau.at/wpcontent/uploads/2017/11/zgh-veroeffentlichung-bd-14.pdf. Accessed 21 Mar 2018 
8. Krammer, K.: Schriftsprachkompetenz gehörloser Erwachsener. Veröffentlichungen des Forschungszentrums für Gebärdensprache und Hörgeschädigtenkommunikation, Band 3. Forschungszentrum für Gebärdensprache und Hörgeschädigtenkommunikation, Klagenfurt (2001)

9. Krausneker, V.: Viele Blumen schreibt man "Blümer". Soziolinguistische Aspekte des blingualen Wiener Grundschul-Modells mit Österreichischer Gebärdensprache und Deutsch. Sozialisation, Entwicklung und Bildung Gehörloser, Band 3. Signum, Hamburg (2004)

10. Krausneker, V., Schalber, K.: Sprache Macht Wissen. Zur Situation gehörloser und hörbehinderter SchülerInnen, Studierender \& ihrer LehrerInnen, sowie zur Österreichischen Gebärdensprache in Schule und Universität Wien. Abschlussbericht des Forschungsprojekts 2006/2007. Auftraggeber: Innovationszentrum der Universität Wien, Verein Österreichisches Sprachen-Kompetenz-Zentrum (mit Unterstützung der Abt I/8 des bm:ukk). Fassung 2 (2007). http://www.univie.ac.at/oegsprojekt. Accessed 21 Mar 2018

11. Swanwick, R., Gregory, S.: Sign Bilingual Education: Policy and Practice. Douglas McLean Publishing, Coleford (2010). https://doi.org/10.1080/13670050903474069

12. Trovato, S.: Insegno in segni. Linguaggio, cognizione, successo scolastico per gli studenti sordi. Raffaello Cortina Editore, Milano (2014)

13. Vollmann, R., Eisenwort, B., Holzinger, D.: Zweitsprache Muttersprache: Die schriftsprachliche Deutsch-Kompetenz österreichischer Gehörloser. Zeitschrift für Interkulturellen Fremdsprachenunterricht 5(2) (2000). http://tujournals.ulb.tu-darmstadt.de/ index.php/zif/article/view/622/598. Accessed 21 Mar 2018

14. Volterra, V., Bates, E.: Selective impairment of Italian grammatical morphology in the congenially deaf: a case study. Cognit. Neuropsychol. 6(3), 273-308 (1989)

Open Access This chapter is licensed under the terms of the Creative Commons Attribution 4.0 International License (http://creativecommons.org/licenses/by/4.0/), which permits use, sharing, adaptation, distribution and reproduction in any medium or format, as long as you give appropriate credit to the original author(s) and the source, provide a link to the Creative Commons license and indicate if changes were made.

The images or other third party material in this chapter are included in the chapter's Creative Commons license, unless indicated otherwise in a credit line to the material. If material is not included in the chapter's Creative Commons license and your intended use is not permitted by statutory regulation or exceeds the permitted use, you will need to obtain permission directly from the copyright holder. 